of doctors. Mr. Flexner's Prussian idea of one doctor to every 2,000 population does not work in this country where a jopular legislature and not the Kaiser's Kultus-Minister has the say in this matter.

Of late years the medical education theorist-Flexner is the type-has been raising the requirement for medical licensure to correspond with intramural conceptions. On the other hand, the public through the legislatures has been creating osteopaths and the like, to supply themselves with medical service outside of the regular profession; these two processes go on pari passu. The higher the professional requirement beyond i certain point-alceady passed in some states-the wider the loors for irregular "paths" and quackery are opened. It takes no prophet to see that if the medical theorist keeps forcing his hobby we shall soon have several legal medical professions in this country. How would it be if the general practitioner. the one who knows the needs of the people he is serving, were given a hearing on this question?

Cinristian Jounsox, M.D., Willmar, Minn.

[CoMmext:-Ou correspondent apparently misunderstands the argument. Mr. Flexner did not intend to imply that the Irussian ratio was applicable to this country. In the report referred to, at the bottom of page 16 and the top of page 17 , it is distinctly stated: "We are not now arguing that a ratio of $1: 1500$ is correct . . Our contention is simply that, starting with our present overcrowded condition, production henceforth at the ratio of one physician to every increase of 1,500 in population will prevent a shortage, for the next generation at least." And in order to avoid any possible misunderstanding, the word "increase" in the report is in italies. As to the reluctance of well-trained physicians to locate in small towns, the same is apparently true of graduates of low grade colleges. Regarding such localities, Mr. Flexner says, (p. 15) "A century of reckless overproduction of cheap doctors. . . has not forced doctors into these hopeless spots." Furthermore, Mr. Flexner makes the suggestion on page 16 that, as a last resort, possibly the best way to get good men to go to unpromising locations is for "the several states to salary district physicians in thinly settled or remote regions."-ED.]

\section{The Plague in China}

[Dr. Hiram Woods of Baltimore sends the following extract from a letter from a missionary in Paoting-Fu, China, who is supported by the First Presbyterian church of Baltimore.]

Feb. 5, 1911: We are in the midst of a siege of plague, This plague started in Harbin, Ianchuria, late in November, or early in Decenber, last year. The Chinese were very slow to take hold of it, and so it got a big start. Then other nations (Russia and Japan) said something must be done or they must interfere to stop its ravages. China, fearing lest these nations should get a greater foothold than they now have, asked for volunteers in our Union Medical College in Peking. Four men came forward to help. The Chinese also used the medical staff and the students in their two medical colleges in Tientsin. A professor from one of these colleges, Dr. Mesny, a Frenchman, went up, took plague and died, as did also one of his students.

The Chinese have been doing what they can to stop it in the original focus and in other places whence it has spread, but up to the present very little progress has been made in checking the epidemic. The medical missionary force has taken a leading part in the work everywhere, and one physician has died in Mukden, Dr. Johnson of the Scotch Presbyterian Mis. sion. He secms to have taken every precaution, wore a respirator and covered himself well. He was a young man, very careful and conscientious, but his work of disinfection and segregation took him into crowded places.

This epidemic is not the bubonic form of plague but the pueumonic. It has been found that the greatest danger is air-borne infection; respirators are very necessary, therefore, when one comes in contact with infected individuals. Rats have been exarsined and no infection found in them. The government was very slow in stopping the trains, and the diesase was carried into China proper, and now it is present at many places in this province and in Shantung. Manv workmen from these two provinces work in Manchuria. and when the plague broke out there they left for home. If the government had stopped the train service early, it could have prevented spread of the disease south of the government wall.

An individual only lives about two or three days, at most six, after taking the disease. There has not been a recovery in an authenticated case. A family came from Harbin to their home about 12 miles from here, and after arriving at home almost all the members were taken ill and died; other families were then taken ill. In all thirty-six persons have died in that small village. Two army physicians have gone down there to see what can be done in the way of isolating the families who lave had plague and burning the houses and contents.

The officials have asked me to take charge of the sanitation of the city here and we have organized a plague prevention league. We meet every day and discuss measures by which we can prevent the plague from entering the city. Up to the present, we have had no authentic cases. Dr. Dilley of our mission in Peking, has kindly come to my assistance. He has taken charge of the hospital which we have prepared hurriedly for "suspects" and also takes the exminations of trains. We have been examining all passengers on the south-bound trains in order, if possible, not to allow the disease to spread further. We have heard of another place, 35 miles south of this city, where thirty persons have died in four villages. These villages will be examined and restrictive measures put on the migration of people. We are trying to instruct the entire police force here by daily lectures, lasting for an hour, so that if the disease should break out we will have some intelligent men to cope with it, who will know how to take a man to the hos. pital or a corpse to the cemetery without infecting themselves; and another batch to follow them in disinfecting houses. We are having all inns inspected twice every dlay so as to discover sick persons early and get them off to the "suspects" camp. We have three native doctors to help us; we ought to have fifty to do the work that should be done here to stop the ravages of plague if it gets into this city.

I have turned over my entire hospital force to the government service in this time of need, and I hope that this work with the officials may give us the opportunity to show them that we are not simply a cranky religious sect, but men who love our fellow men and serve our God, who is worthy of being their fod and Savior.

I do not know when we will ever be able to do medical work, that is, to open our hospital here. of course, if we got plague into it, we would be in a bad way, for it is said that burning is the only safe way to disinfect a building. I am afraid North China is in for a serious time for many years, and that our mission work will suffer much for this. It will be almost impossible to go to the country to work, as one would be constantly running into plague, and if this virulent form persists it means sure death to any one who takes the disease; as I have said, no one recovers. One can hardly dare to imagine the future of poor China for the next few months. The heat may stop the disease in a few months or so, or it may appear in bubonic form, when the fiea season comes, and kill half the population; no one can tell. I wish America would show her friendship for this needy land now, and send out fifty sanitary engineers to cope with this awful pest, and thus save millions of lives that are worth saving. Can't you stir up President Taft or some big man to do this?"

Chartes Lew is, M.Đ.. Paoting-Fu, China.

Plyysician in Charge, The Taylor Memorial Hospital.

\section{The Secret Commission Evil}

To the vditor:--I have read with great interest the article and editorial on "The Secret Commission Evil," in The JourNAL, March 11. I am glad to see the Association take such a position, as here in Kansas, commission-giving is practiced to an appalling extent. I have been offered a commission from the owner of a private hospital on the hospital fees of any patients I might send. A dentist friend of mine tells me he has been approached by a physician with a suggestion that he give a commission on patients that he might send to him, and 
that this was not an uncommon practice. In Topeka, the ruling commission is 40 per cent, but one man has advanced it to 75 per cent.

In the last session of the legislature, the medieal department of the university was interested in some bills which were introduced by a physician. A good friend of the institution told me that I had made a mistake in having a physician introdnce any bills, as it always created a suspicion of graft and crookedness, and the members were very slow to accept it on that account.

I hardly know whether we can control this evil in Kansas or not. I have on file a letter, in reference to a statement that I made in regard to this thing, from a general practitioner which reads as follows: "I am surprised at the enclosed clipping. How many of the best surgeons in the state can you name who will not 'split the bill?' I do not know a surgeon in the state who would hog the whole thing."

I am afraid that this represents the feeling of a large percentage of physicians over the state. However, any help that you can give us in combating this evil will be greatly appreciated by at least some of us.

Mervin T. Sudier, M.D., Lawrence, Kans.

\section{Queries and Minor Notes}

Axoxmous Commexictioxs will not be noticed. Every letter must contain the writer's name and address, but these will be onitted, on request.

\section{JOURNALS ON SEXUAL PHENOMENA}

To the Editor:-Please publish in your Department of Queries and Minor Notes the names of journals published in English or other language devoted to the study of sexual phenomena in any of their scientific aspects.

Josfph H. Toosey, M.D., Chelsea. Mass.

ANSwER.-So far as we know. the only journals devoted specifically to sexual phenomenon which are still being published are the following :

Die neue Generation, monthly official organ of the Bund fiir Mutterschutz, edited by Helene Stöcker, Berlin, Germany.

Sexual-Probleme, monthly, published by J. D. Saueranders, Frank-

fort on the Main. Germany.

Several others (chicfly German) have been discontinued. The transactions of screral socicties interested in the subject are publisbed periodically. The transactions of the third congress of the Deutsche Gesellschaft zur Bekämpfung der Geschlechtskrankheiten are published under the title of "Sexualpiidagogik."

\section{SANITATION AND CIVILIZATION}

To the Editor:- What evidence have we that our sanitary and other measures (in the broadest sense) are of ultimate value as other measures to the fatalistic neglect of such measures among Oriental nations? For cxample if we reduce the number of deaths from tuberculosis, or from al infectious diseases, may not other discases evolution?

I have in mind a comparison, in a broad way, of the span of life and the nortality (per' 100.000 ) among savage and civilized races through a period of centuries rather than years, as well as the span of life and

I bave in mind also the immunity gradually accuired to diseases such as syphilis and measles (as in south Sea Islands), where such cicrastation occurred. I am thinking also of the law. "a rise in birth-rate entails a rise in death-rate, ind rire rersa." and in arger way "of life on a basis subsistence" aceording to Malthus

Axswer.-A full discussion of the subject proposed by our correspondent would consume more space than would be profitable for 'Tre Joursal to devote to it. The data as to mortality in uncivilized or partly civilized countries are not sufficiently accurate to afford a safe basis for comparison. Of coul'se, the early infant mortality in uncivilized countries tends to the survival of strong individuals as the wak die out. This is, however, a loss. for many such individuals who are weakly.in childhood grow up under favorable circumstances to become vigorous adults of great value to the statc. It is amply demonstrated that civilized communities tend to increase in population to a greater extent than savage tribes, and this is largely due to hygienic progress and sanitary laws. The fact that the Indians in this country are dying out shows the operation of insanitary conditions in spite of long habituation which ought to have brought immunity and prolonged life if the theory under discussion were trie. See also abstract of Plinzing's paper on this subject in the Berlin Letter, March 4, 1911, p. 682.
FTIQUETTE OF CALLS BY NEWCOMER

To the Editor-I'lease give the ethics of calling for doctors locating in new territory. Should the newcomer call first on resi-
dent practitioners? Is the old custom reversed? E. R. Barney, Wattsburg, Pa.

Axswer.- Several years ago The Jovrnal answered this question, but because of the time that has elapsed, we repeat: "It is an accepted custom for young physicians and newcomers to eall on the older physicians and those of longer sidence in the locality. It is a malli of courtesy and respect due from one locat ing in a new place. Ile thus announces his arrival and his desire to be rcognized in profossional circles and friendships." Some correspondence followed this "answer," which made it cvident that this custom is sometimes confused with that which governs social relations when a family moves into a new locality.

\section{THYROH IN HEMOPHILIA}

To the Editor:-In reply to the communication of Dr. N. C Miller in THE JovrNaI, of March 18, I would like to recommend thyroid extract for his cases of hemophilia. In the Amnals of Surgery, May, 1907, I published an account of a case cured by this drug after I had exhausted all the ordinary methods of treat ment. I always give thyroid extract in eases in which I suspect a tendency to blend or in which any such tendeney is shown. Also in cases of disturbed metabolism whoid gives good results.
thyrota

\section{REMOVAL OF ADHESIVE PLASTER}

To the Editor:-A little lard or hydrated wool fat (Ianolin) rubbed into adhesive plaster will loosen it in a very few minutes and is much less unpleasant than gasoline or any other substance I have seen recommended in the recent discussion of this subject [Jan. 28, Feb. 25, and March 4, 1911]. Also, it can usually be
found in crery bouse.
$\mathrm{H}, \mathrm{R}$. Costox, Birmingluam, Ala.

\section{The Public Service}

\section{Medical Department, U. S. Army}

Changes for the weok ended March 25, 1911

Love, Joseph W.. M.R.C., March 17. ordered to proeecd from Fort Preble, Maine, to Fort Banks. Mass., for duty at that post

Newton, Ralph W., March 17 , oldeled to proced, about A pril 15 1911, from Fort IRevere, Mass., to Fol't Andrews, Mass., fol duty at that post.

Brooke, John D., and Iull, Alva R., cont. surgeons, March 11 entered into for duty is cont. surgeons, U. S. Army.

Eyster, Grorge I., March 20 , entered into for duty as cont. surgeon, $\mathbf{C}$. S. Alny.

The following named officers of the M. R. C. will proceed to San Diego, Cal., and report in person to the commanding general of th maneuver camp at that place for duty: First Licutenants Alleyne von Schrader, William T. Cade, Jr., Herbert $H$. Sharpe, James F.
Johnson, Bert R. Huntington, Harry G. Ford, l'aul W. Gibson, Francis $x$. Strong and lobert $\dot{C}$. McDonald.

The following named officers of the Medical Reserve Corps will proceed to San Antonio, Texas, and report to the commanding general the mancuver division, for duty : First Lieutenants George E. Pariseau, Lauren S Eckels, Lloyd A. Kefauver, John S. Coultel. Thomas J. Flynn, Frederick H. Foucar, Joseph i. Siner, John IR. MeKnight, Eugrene G. Northington, Samuel S. Creighton, Robert $\mathrm{I}$. Cantt, Edward C. Register, William Denton, George C. Divins, Howard clarke, clemens W. Mclillan, Sanford w, French, Joseph o. Walkup, Iorace M. Robcrson. Leonard S. Hughes, charles 1 . IcBrayer, George B. Lake. Fred R. Burnside, Albert F'. Clark, Dan iel F. Maguire, Raymond W. Mills, Henry C. Maddux, Jay 1 . Whitham, Lro C. Mudd, Josiah H. Holland, John M. Willis, John J. Reddy, James I. Robinson, Henry C. I

Schreimer is IR major, Iarch 16, reports arrival at Douglas Ariz, with headquarters $3 d$ Squadron and Troops $I$ and $K$, 1 st Cavalry.

Wolven, IYomer F.. I).S., March 12, returned to Yancourer Balracks, Wash., from temporary duty at Boise Bar'tacks, Idaho.

Lynch, Charles. March 20 , detailed to take charge first aid department of Imerican National Red cross.

Brown, Ira (. M.R.C.. Marcb 18, ordered from Fort lawton, Wash.. to Fort loouglas, Utah, for temporary dut

Craft. Edgar D., II.k.C. March 21, relieved from duty at the Army Medical school in this city and ordered to Walter liecd Gen eral Hospital, Takoma Iark. I. C.. for duty.

Hemans, II. IF. II.R. ( March 14 ordered to procecd from Fort wayne to Fort lirady. Mich., for temporary duty.

Grifis. Frank C.. M.iR.C. Mareh 20, ordered to proceed from Fort D. A. Russell, Wyo., to Fort Robinson, Neb., for temporary duty.

\section{Medical Corps, U. S. Navy}

Changes during the weck ended Mareh 2\%, 1911

Farenholt, A., surgeon, detached from the naval hospital, Puget Sound, Wash., and ordered to the marine recruiting station, San Francisco.

Smith. W. B., I'. A. surgeon, detached from the marine recruiting station, San Francisco, and ordered to the Naval Mredical School. Washington. 1$)$. C., for instruction.

Mecornick, A. M. D. medical inspector, commissioned medical inspector from Feb. 8,1911 . 